\title{
Aikalaisanalyysi epävarmasta työstä ja äitiydestä
}

Rokkonen, Lilli Aini: Prekaari äitiys. Kertomuksia palkkatyön reunamilta. Publications of the University of Eastern Finland, Dissertations in Social Sciences and Business Studies 235. Joensuu: Itä-Suomen yliopisto, 2020, 324 sivua.

Lilli Rokkosen teos Prekaari äitiys. Kertomuksia palkkatyön reunamilta on yhteiskuntapolitiikan väitöskirja. Se käsittelee haurastunutta työelämää ja intensivoitunutta äitiyttä nyky-Suomessa. Feministisiksi solidaarisiksi syvähaastatteluiksi kutsuttujen haastattelujen ja narratiivisen analyysin keinoin toteutettu tutkimus tarkastelee nykyäitiyttä prekaariksi tekeviä prosesseja ja mekanismeja. Tutkimusaineiston muodostavien 13 alle kouluikäisen lasten äidin haastattelun kautta tarkastellaan myös äitien toimintatilaa, kokemuksia ja tunteita.

Prekaarius syntyy siitä, että haastatellutäidit sijoittuvat perinteisen, kokoaikaisen, koulutusta vastaavan, vakaan ja tyypillisen palkkatyön reunamille. Työmarkkina-asema voi olla prekaari niin luovilla aloilla ja hoivatyössä kuin abstraktissa asiantuntijatyössäkin, oli työn muoto sitten koko- tai osa-aikainen yrittäjyys, palkkatyö tai näiden ja opiskelun ja lasten hoivan yhdistelmä. Palkkatyön reunamilla Rokkonen tarkoittaa asemia, joissa ihmisillä on jonkinlainen kiinnitys kokoaikaiseen ja pysyvään palkkatyöhön - he eivät ole täysin sen ulkopuolella mutta eivät sen ytimessäkään. Jonkinlainen suhde muodostuu silti väistämättä, koska sekä perheasemat että toimeentulo- ja varhaiskasvatusjärjestelmä ovat rakentuneet palkkatyöinstituution varaan.

Rokkosen prekarisaatiokäsitys on laaja: se on työn yleistä haurastumista, joka koskee vähintään potentiaalisesti laajaa joukkoa ihmisiä. Prekarisaatio ulottuu myös työn haurautta laajemmalle, elämän yleiseen epävarmistumiseen. Rokkonen pyrkii tekemään aikalaisanalyysiä elämisen ehdoista ja affektiivisuudesta, prekaareista tunteista, sen sijaan että suppeammin kartoittaisi prekaarin työn ryhmiä, syitä ja seurauksia. Näin hän huomaa esimerkiksi, kuinka ihminen voi tuntea huolta työtilanteestaan silloinkin, kun siihen ei näytä olevan perusteltua syytä. Siksi työtä ja elämää koskevat tunteet tulevat välttämättömäksi osaksi prekarisaation analyysiä. Juuri prekaarissa, pätkittäisessä ja epävarmassa työssä työn ja muun elämän rytmit ovat hallitsemattomia ja keskenään epätahtisia ja siksi omiaan tuottamaan tiettyjä tunteita. Prekarisaatio ei pelkisty työmarkkina-asemiin: sukupuolten, äitiyden, hoivan ja työmarkkinoiden sukupuolistuneisuus luovat rakenteen, johon eletty prekaarisuus kytkeytyy.

Tutkimus tuo esille, että prekaari työmarkkina-asema voi olla myös itse valittu, sellaiseksi kerrottu tai tietyn alan normaali. Asema työmarkkinoiden reunoilla voi lisätä vapautta ja mahdollistaa oman näköistä elämää ja toimijuutta. Kääntöpuoli on jatkuvan suojattoman aseman ja itseriiston riski. Voi olla, että työmarkkina-aseman prekaarisuus tulee ongelmaksi vasta jonkinlaisessa elämän käännekohdassa, kun turvaton asema manifestoituu esimerkiksi työsuojelun tai työterveyden puutteena tai minimiäitiyspäivärahana.

Rokkonen tarkastelee prekarisaatioilmiötä juuri äitiyden kontekstissa. Tutkimus sijoittuukin myös yhteiskuntatieteellisen äitiystutkimuksen perinteeseen. Tutkija toteaa lastensaamisen lähtökohtaisesti prekaariksi, epävar- 
maksi ja ennustamattomaksi tilanteeksi, jossa vastuu yhä helposti luonnollistuu äideille. Epävarmuutta lisää äitiyden intensivoituminen eli se, että lasten kasvattaminen edellyttää tunne-, paikka- ja tietointensiivistä omistautumista, tiedostamista ja läsnäoloa, mikä vie aikaa. Kun samanaikaisesti naisiin kohdistuu arvolatautuneita odotuksia myös urasta, taloudellisesta itsenäisyydestä ja omasta paikasta työelämässä, odotukset ovat kokonaisuudessaan suuria ja ristiriitaisia. Rokkonen huomaa tästä ristiriidasta syntyvän vastatarinoita, kuten halua jättäytyä työn sävyttävän äitiyskerronnan ulkopuolelle edes hetkeksi, vaikka se tarkoittaisi vielä prekaarimpaa asemaa. Toisaalta prekaarit asemat voivat johtaa perinteisten perheensisäisten työnjakojen uudelleenneuvotteluihin. Jos koko perheen työajat, -paikat ja -muodot ovat epätyypillisiä, hoiva saattaa jakautua tasa-arvoisemmin kahden vanhemman tehdessä työtä silloin, kun sitä on. Tutkimus näyttää, miten ratkaisut ovat kuitenkin perhe- ja yksilökeskeisiä, eivätkä yhteiskunnalliset järjestelmät taivu helposti auttamaan epätyypillisen työn ja hoivan yhdistämisessä. Jää ennen kaikkea naisten harteille järjestää ensisijaisesti hoiva ja toissijaisesti oma työnsä.

Tutkimuksessa pohditaankin yhteiskuntapolitiikan roolia, naisystävällisen hyvinvointivaltion politiikan muutosta ja sen seurauksia naisille, joille julkinen sektori on merkittävä työllistäjä ja työnteon mahdollistaja. Esille tulee, kuinka sukupuolistuneet hoivasuhteet asettavat äitejä yhä prekaareihin asemiin.

Pidän tutkimuksen yhtenä tärkeimpänä sanomana sitä, että prekaareissa tilanteissa itseään on vaikea sijoittaa sen paremmin ammattiasemien tai työmuotojen mukaisiin lo- keroihin kuin kotiäiti/työssäkäyvä äiti -kategorioihinkaan. Rokkonen on erityisen tarkkanäköinen analysoidessaan äitien lastenhoitoratkaisuja, jotka niin äitien kesken kuin tutkimuskirjallisuudessakin esitetään varsin kaksinapaisesti kotihoito-päivähoitokiistoina. Rokkonen näyttää, miten prekaari asema estää tekemästä lukkoon lyötyjä tai edes oman ideaalin mukaisia hoitoratkaisuja, kun vaihtuvat työtilanteet pakottavat olemaan varpaillaan ja valmiina muutoksiin. Kodin kynnyksellä oleminen on osuva metafora. Työt eivät asetu vakituisen, kokoaikaisen palkkatyön rytmiin - eikä sitä myöten muukaan elämä.

Ansiokkaan tutkimuksen ongelma on, että kolmessa analyysiluvussa käydään läpi runsaasti teemoja. Tutkimuksessa tehdään ikään kuin monta pienoistutkimusta analyysin sisällä. Niihin on löydetty asiantuntevasti olennaiset viittaukset ja uskottavat tulkinnat, mutta näitä "tutkimuksia tutkimuksessa" tulee monta ja niiden " $n$ " on pieni, kun esimerkiksi hoivatyöstä tai yrittäjyydestä jää kertomaan vain pari naista. Pieni karsiminen, tiivistys tai jalostetumpi rakenne analyysilukujen sisällä olisi saattanut terävöittää sanomaa. Suosittelen teosta kuitenkin lämpimästi kaikille työelämän epävarmistumisen trendeistä kiinnostuneille. Työelämän tutkijoiden ja kehittäjien on tärkeää ymmärtää epävarmuuden elämisen ehtoja.

\section{Kirjoittaja}

Hanna-Mari Ikonen, HTT, dos., yliopistonlehtori, Jyväskylän yliopisto, sähköposti: hanna-mari.p.ikonen@jyu.fi twitter: @hansuikonen 